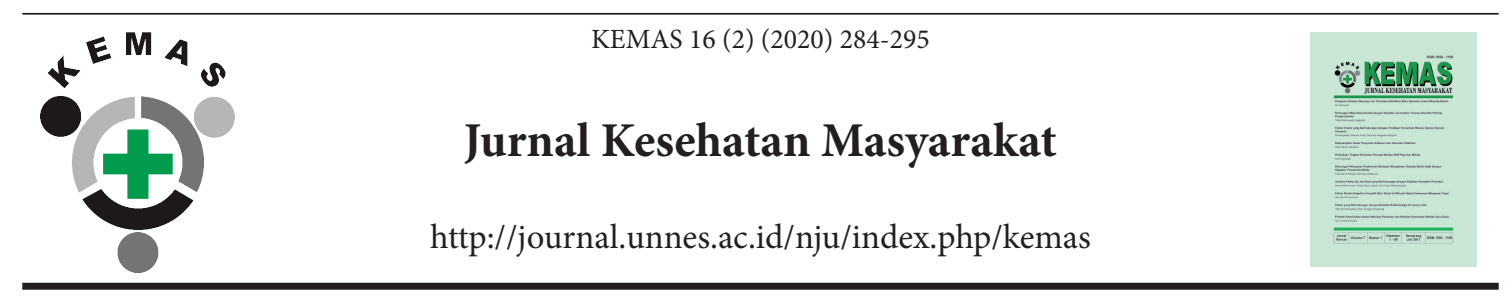

\title{
Potency of Bioactive Compound of Rice Bran for Colon Cancer Prevention
}

\author{
Safrida $^{1}$, Slamet Budijanto ${ }^{1 凶}$, Lilis Nuraida ${ }^{2}$, Bambang Pontjo Priosoeryanto ${ }^{3}$ \\ ${ }^{1}$ Department of Food Science and Technology, Bogor Agricultural University, Bogor, Indonesia. \\ ${ }^{2}$ Southeast Asian Food and Agricultural Science and Technology (SEAFAST) Center, Bogor Agricultural \\ University, Bogor, Indonesia. \\ ${ }^{3}$ Department of Veterinary Clinic Reproduction and Pathology, Bogor Agricultural University, Bogor, \\ Indonesia.
}

\section{Article Info}

Article History:

Submitted September 2019

Accepted April 2020

Published November 2020

Keywords:

Rice bran, Bioactive

compound, Colon cancer.

DOI

https://doi.org/10.15294/

kemas.v16i2.2133

\begin{abstract}
Colon cancer is the second leading cause of death in the world. Bioactive compounds in rice bran have a very active role as antiproliferation of colon cancer cells such as ferulic acid, p-coumaric acid, caffeic acid, gallic acid, protocatechuic acid, sinapic acid, tricin, luteolin, apigenin, myrecitin, rutin, isorhamnetin, $\gamma$-oryzanol, $\gamma$-tocopherol, $\delta$-tocopherol, $\gamma$-tocotrienol, $\beta$-sitosterol, phytic acid, and hemicellulose. Mechanism of the bioactive compounds in cells varied, including modulation of a cell cycle, activation of immune cells, damage of a lipid layer and mitochondrial membrane, activation of caspase proteins, inhibition of protein cell tumor invasion, metastasis, and angiogenesis, and also acts as an antioxidant. Therefore, the existence of the scientific studies results of this review with the potential availability of adequate rice bran in Indonesia is very potential to be developed.
\end{abstract}

\section{Introduction}

Bioactive compounds are phytochemicals that can be found in food, serves to modulate metabolic processes to improve health. The bioactive compounds in rice bran have been widely known that have a role in reducing several diseases such as hyperlipidemia (Um et al., 2013), antiproliferation in cancer cells (Hui et al., 2010; Zulfafamy et al., 2018; Islam et al., 2017; Ghoneum \& Agrawal 2011), antidiabetic (Ardiansyah et al., 2006; Noviasari et al., 2019; Kurniawati et al., 2016), chronic kidney disease and acute coronary syndrome (Rashid et al., 2015).

Rice bran is a by-product of the rice milling process. In the process of rice milling, $10 \%$ of rice bran will be produced. The potential of rice bran that produced was estimated at 5.65 million tons in Indonesia in 2018 (Badan Pusat
Statistik, 2018). However, the use of rice bran in Indonesia is generally still limited to animal feed (Tuarita et al., 2017).

Several bioactive compounds in rice bran had the potency to inhibit colon cancer cells, that were specifically reported, namely $\gamma$-tocotrienol (Xu et al., 2012), $\gamma$-oryzanol (Kim et al., 2012), and ferulic acid (Janicke et al., 2011). Inhibition of cancer cell proliferation by utilizing the potential of rice bran bioactive compounds is preventive prevention (Law et al., 2017), while curative prevention is a type of treatment that has long been applied, such as surgery, radiotherapy, and chemotherapy. Chemotherapy treatment is often reported to cause effects on other organs (Focaccetti et al., 2015). The chemotherapy agents have been commonly used, in patients with colon cancer are leucovorin, capecitabine, irinotecan, 
oxaliplatin, and 5-fluorouracil (Nasrallah \& Sibai, 2014).

Colon cancer itself was ranked the second highest cause of death in the world in 2018 (Bray et al., 2018). While in Indonesia, ranked the third highest (equivalent to the percentage of people with lung cancer), with the number of incidents in 2018 of 15.245 people, and will continue to increase until 2040 with an estimated number of 27.354 people, based on the 2018 Global Cancer Data (IARC, 2018). This disease is caused by two main factors, namely internal factors (5-10\%) including genetic factors, and external factors (90-95\%) such as stress, obesity, radiation, and bad dietary as the biggest contributing factor that is $30 \%$ to 35\% (Anand et al., 2008). The effort of preventing cancer can be done, among others, by consuming functional food products. Rice bran which contents the bioactive compound can be used as ingredient for development of functional food products.

This article will review the potential of bioactive compounds in rice bran as the prevention of colon cancer. Scientific studies of bioactive compounds and their mechanisms for colon cancer will be reviewed in this article, which will be shown in the form of mapping. Furthermore, the development of rice bran as functional food will also be discussed to provide an illustration of the extent rice bran has been applied as a functional food.

Bioactive Compounds in Rice Bran and its Function

Even though rice bran is a byproduct of the rice milling process, it contains many essential nutrients such as vitamins, minerals, amino acids, antioxidants (Younas et al., 2011), bioactive compounds, fats (Alauddina et al., 2017), and dietary fiber such as $\beta$-glucan, pectin, and gum (Prasad et al., 2011). Fatty acids are dominated by linoleic (31-33\%), oleic (37-42\%), palmitic (21-26\%), and also high in content of polyunsaturated fatty acids, which are known to be good for health (Oliveira et al., 2011).

Antioxidants have been reported that has a role in protecting cell damage due to oxidative stress resulting from the formation of free radicals, the oxidative stress is the main cause of cancer cases (Kumar, 2014). Groups that act as antioxidant compounds are phenolic acids, anthocyanins, flavonoids, tocotrienols, tocopherols, $\gamma$-oryzanol, and phytic acid (Goufo et al., 2014). These groups are found in rice bran. The amount of bioactive compound and nutrient content in rice bran can be seen in Table 1.

Pigmented rice bran has been reported that is rich content in anthocyanin and proanthocyanidin. Both of them have a contribution to pigmented of rice, antioxidant (Limtrakul et al., 2019; Anggraini et al., 2015), anti-inflammatory (Limtrakul et al., 2016; Xia et al., 2006), and anthocyanin also act as cytotoxic activity (Pratiwi \& Purwestri, 2017). AbdelAal et al., (2006) reported, the anthocyanin in black rice bran contained $3.276 \mathrm{mg} / \mathrm{g}$ and red rice bran contained $0.094 \mathrm{mg} / \mathrm{g}$. While Hosoda et al., (2018) reported, that anthocyanin was only detected in black rice with the highest concentration, namely the Minenomurasaki cultivar $(5.045,6 \mu \mathrm{g} / \mathrm{g})$, while red rice was dominated by the proanthocyanidin component in the Yuyakemochi cultivar $(3.060,6 \mu \mathrm{g} / \mathrm{g})$. The variation in the amount of anthocyanin content is due to differences in rice cultivars and location of growth (Alauddina et al., 2017).

The compound of $\beta$-carotene and lycopene have been reported that it very contributes to the reddish-brown appearance, and both of them are precursors of vitamin A, which can act as antioxidants in the biological system (Lamberts et al., 2016). $\beta$-carotene and lycopene are part of the carotenoids. These carotenoids are able to bind singlet oxygen and to trap free peroxyl radicals, and it is called photoprotective agents (Manickavasagan et al., 2017). Brown rice bran was reported that contains dietary fiber which was four times higher than the white rice (Sun et al., 2010; Limtrakul et al., 2019), contained essential amino acids such as lysine (Limtrakul et al., 2019), and rich in content of vitamins, such as niacin (3.5-5.3), riboflavin (0.04-0.14), thiamine (0.29-0.61), and tocopherol (0.90 -2.50), units of measurement were shown here as $\mathrm{mg} / 100 \mathrm{~g}$ of flour (Manickavasagan et al., 2017).

The bioactive component of $\gamma$-oryzanol which is present in rice bran (black, red, brown) was reported that had an antioxidant activity of 10 times higher than tocopherol, while 
Table 1. Groups of bioactive compounds in rice bran

\begin{tabular}{|c|c|c|c|c|}
\hline \multirow{2}{*}{ Bioactive compound } & \multicolumn{3}{|c|}{ Column Header Goes Here } & \multirow{2}{*}{ Reference } \\
\hline & Black & Red & Brown & \\
\hline \multicolumn{5}{|l|}{ Phenolic acids } \\
\hline Protocatechuic acid (mg/100g) & 6.18 & 5.31 & 2.87 & Ghasemzadeh et al. (2018) \\
\hline p-coumaric acid (mg/100g) & 33.35 & 24.53 & 16.71 & Ghasemzadeh et al. (2018) \\
\hline Ferulic acid (mg/100g) & 28.04 & 23.83 & 17.79 & Ghasemzadeh et al. (2018) \\
\hline Cinnamic acid (mg/100g) & 25.53 & 15.33 & 9.61 & Ghasemzadeh et al. (2018) \\
\hline Syringic acid (mg/100g) & 24.40 & 21.50 & 14.42 & Ghasemzadeh et al. (2018) \\
\hline Sinapic acid $(\mu \mathrm{g} / \mathrm{g})$ & 252.10 & 209.80 & 258.7 & Laokuldilok et al. (2011) \\
\hline Gallic acid $(\mu \mathrm{g} / \mathrm{g})$ & 161.10 & 39.00 & 25.10 & Laokuldilok et al. (2011) \\
\hline Hidroxybenzoic acid ( $\mu \mathrm{g} / \mathrm{g})$ & 443.30 & 52.50 & 68.90 & Laokuldilok et al. (2011) \\
\hline Vanillic acid (mg/100g) & 36.930 & 13.83 & 0.98 & Pang et al. (2017) \\
\hline Isoferulic acid (mg/100g) & 7.340 & 8.39 & 12.34 & Shao et al. (2014) \\
\hline Caffeic acid $(\mu \mathrm{g} / \mathrm{g})$ & 16.900 & 24.20 & - & Sumczynski et al. (2016) \\
\hline \multicolumn{5}{|l|}{ Flavonoids } \\
\hline Apigenin (mg/100g) & 15.31 & 6.39 & 4.22 & Ghasemzadeh et al. (2018) \\
\hline Luteolin (mg/100g) & 10.72 & 7.74 & 2.35 & Ghasemzadeh et al. (2018) \\
\hline Catechin (mg/100g) & 22.05 & 15.90 & 8.96 & Ghasemzadeh et al. (2018) \\
\hline Myrecitin (mg/100g) & 12.85 & 12.82 & 5.68 & Ghasemzadeh et al. (2018) \\
\hline Quercetin (mg/100g) & 15.55 & 9.27 & 2.87 & Ghasemzadeh et al. (2018) \\
\hline Tricin $(\mu \mathrm{g} / \mathrm{g})$ & 10.00 & 2.40 & 2.00 & Poulev et al. (2017) \\
\hline Rutin $(\mu \mathrm{g} / \mathrm{g})$ & 2.80 & 4.10 & - & Sumczynski et al. (2016) \\
\hline Isorhamnetin $(\mu \mathrm{g} / \mathrm{g})$ & 0.83 & - & ND & Nakornriab et al. (2008) \\
\hline \multicolumn{5}{|l|}{ Anthocyanins } \\
\hline Cyanidin-3-glucoside $(\mu \mathrm{g} / \mathrm{g})$ & 2316.7 & 179.0 & ND & Laokuldilok et al. (2011) \\
\hline Peonidin-3-glucoside $(\mu \mathrm{g} / \mathrm{g})$ & 245.7 & 9.10 & ND & Laokuldilok et al. (2011) \\
\hline Cyanidin-3-rutinoside $(\mu \mathrm{g} / \mathrm{g})$ & 0.70 & ND & - & Huang \& Lai (2016) \\
\hline \multicolumn{5}{|l|}{ Steroidal compounds } \\
\hline$\gamma$-oryzanol(mg/g) & 9.12 & 8.58 & 1.52 & Moongngram et al. (2012) \\
\hline a-tocopherol $(\mu \mathrm{g} / \mathrm{g})$ & 43.57 & 44.00 & 41.36 & Moongngram et al. (2012) \\
\hline$\gamma$-tocopherol( $\mu \mathrm{g} / \mathrm{g})$ & 35.31 & 25.00 & 37.97 & Moongngram et al. (2012) \\
\hline$\delta$ - tocopherol $(\mu \mathrm{g} / \mathrm{g})$ & 4.28 & 4.30 & 0.25 & Huang \& Lai (2016); Min et al. (2014) \\
\hline a-tocotrienol $(\mu \mathrm{g} / \mathrm{g})$ & 9.99 & 11.49 & 4.36 & Huang \& Lai (2016); Min et al. (2014) \\
\hline$\gamma$-tocotrienol( $\mu \mathrm{g} / \mathrm{g})$ & 53.09 & 45.83 & 32.27 & Huang \& Lai (2016); Min et al. (2014) \\
\hline$\delta$ - tocotrienol $(\mu \mathrm{g} / \mathrm{g})$ & 6.03 & 5.66 & 2.50 & Huang \& Lai (2016); Min et al. (2014) \\
\hline \multicolumn{5}{|l|}{ Others } \\
\hline Protein & 13.27 & 12.93 & 12.07 & Moongngram et al. (2012) \\
\hline Fat & 15.85 & 17.32 & 16.96 & Moongngram et al. (2012) \\
\hline Fiber & 12.68 & 12.11 & 11.77 & Moongngram et al. (2012) \\
\hline Phytic acid & 35.00 & 39.91 & 48.12 & Moongngram et al. (2012) \\
\hline
\end{tabular}


tocotrienol had antioxidant activity 40-60 times higher than tocopherol activity (Alauddina et al., 2017). These are detected much more in black rice bran. However, all rice bran types contain 4-hydroxy-3-methoxycinnamic acid, which is known to have antioxidative effects and photoprotective (Garcia-Conesa et al., 1999).

The Mechanism of Bioactive Compounds in Rice Bran as a Colon Cancer Prevention

The prevention mechanism of colon cancer cells by bioactive compounds in rice bran is reported very diverse, starting from acting as an antioxidant so that it can protect against free radicals, changing the cell cycle, cell antiproliferation, modulating the immune system, inducing apoptosis in the cascade pathway, and protecting the layers mucosa by influencing microbial transformation through high fiber content in rice bran (Henderson et al., 2012).

These mechanisms were also known different, both of the same or different groups of bioactive compounds, such as ferulic and p-coumaric acid, even though both were phenolic compound group, and capable to delay development in the Caco- 2 colon cancer cell cycle, but through a different inhibitory pathway. Ferulic acid delayed on the $S$ phase pathway, affected the centrosome central regulatory genes, and DNA damage checkpoint genes such as CEP2, CETN3, and RABGAP1. While p-coumaric acid induced the G2/M phase pathway and affected other cell cycle regulating genes, such as $\mathrm{MYC}$, CDKN1A, PCNA, CDC25A, ODC1, CCNA2, and CCNB1 (Janicke et al., 2011).

Bioactive compound of p-coumaric acid not only played a role in delaying the cell cycle, but it was also reported to have the inhibitory ability on other mechanisms. Supplementation of $\mathrm{p}$-coumaric acid on albino male rats, which was given procarcinogens 1,2 dimethylhydrazine (DMH) could inhibit glucose-regulated protein (GRP78) which was an indicator of transformation into malignant cancer, besides that, $\mathrm{p}$-coumaric acid was able to mediate apoptosis against unfolded protein response (UPR) activated, which was the key to the development of oncogenic by inhibiting the expression of p-p65 $(\mathrm{NF}-\kappa \mathrm{B})$ and $\mathrm{p}-\mathrm{I} \kappa \mathrm{Ba}$, and reduced inflammation characterized by the decreased cytokine expression, namely COX-2, IL-6, TNF- $\alpha$ and PGE2 (Sharma et al., 2018).

UPR activation was reported to be able to activate anti-apoptotic NF- $\kappa \mathrm{B}$, thus inhibiting apoptotic signals from p53 and inducing angiogenic activity through increased vascular endothelial growth factor (VEGF) (Yadav et al., 2014). The increase of VEGF would cause cancer cells to receive nutrient and oxygen supply so that it was pushed to grow faster, inhibition of VEGF was also known to be regulated by COX-2, 5-LOX (Kim et al., 2012) and GRP78 enzymes through VEGFR-2 mediating signals (Katanasaka et al., 2010).

Another component that is also reported to play a role in inhibiting colon cancer is $\gamma$-oryzanol. Giving $\gamma$-oryzanol as feed to Balb/c mouse transplanted by colon cancer cells CT26, was able to modulate the immune system by improving the function of phagocytosis in macrophages, released pro-inflammatory cytokines, tumor necrosis factor- $\alpha$, IL- $1 \beta$, and IL- 6 by macrophages, increased the activity of natural killer cells $(\mathrm{NK})$, reduced the number of blood vessels in cancer, suppressed vascular endothelial growth factor (VEGF) which was a marker of angiogenesis, and suppressed the COX-2 and 5-LOX enzymes (Kim et al., 2012). Phagocytosis is very important for cells to protect hosts against harmful foreign particles by swallowing and destroying them, and this process is very important as a form of immune response (Pavlou et al., 2017).

Other mechanisms of colon cancer cell inhibition are also reported, namely through the caspase cascade apoptosis pathway. This pathway can kill cancer cells without inflammation and damage to surrounding cells, by mediating by caspase which will produce an active signaling molecule, which acts as the main link in the regulatory network within the cell, so as to control cell death and inflammation (McIlwain et al., 2013). Apigenin (flavonoid group) was reported to be able to increase caspase- 8 expression (initiator caspase), and caspase-3 (caspase executor) in HT-29 colon cancer cells, and could reduce cyclin D1 and rapamycin expression. Cyclin D1 acted as a protein that regulated cell cycles, while rapamycin was used as a clinical 


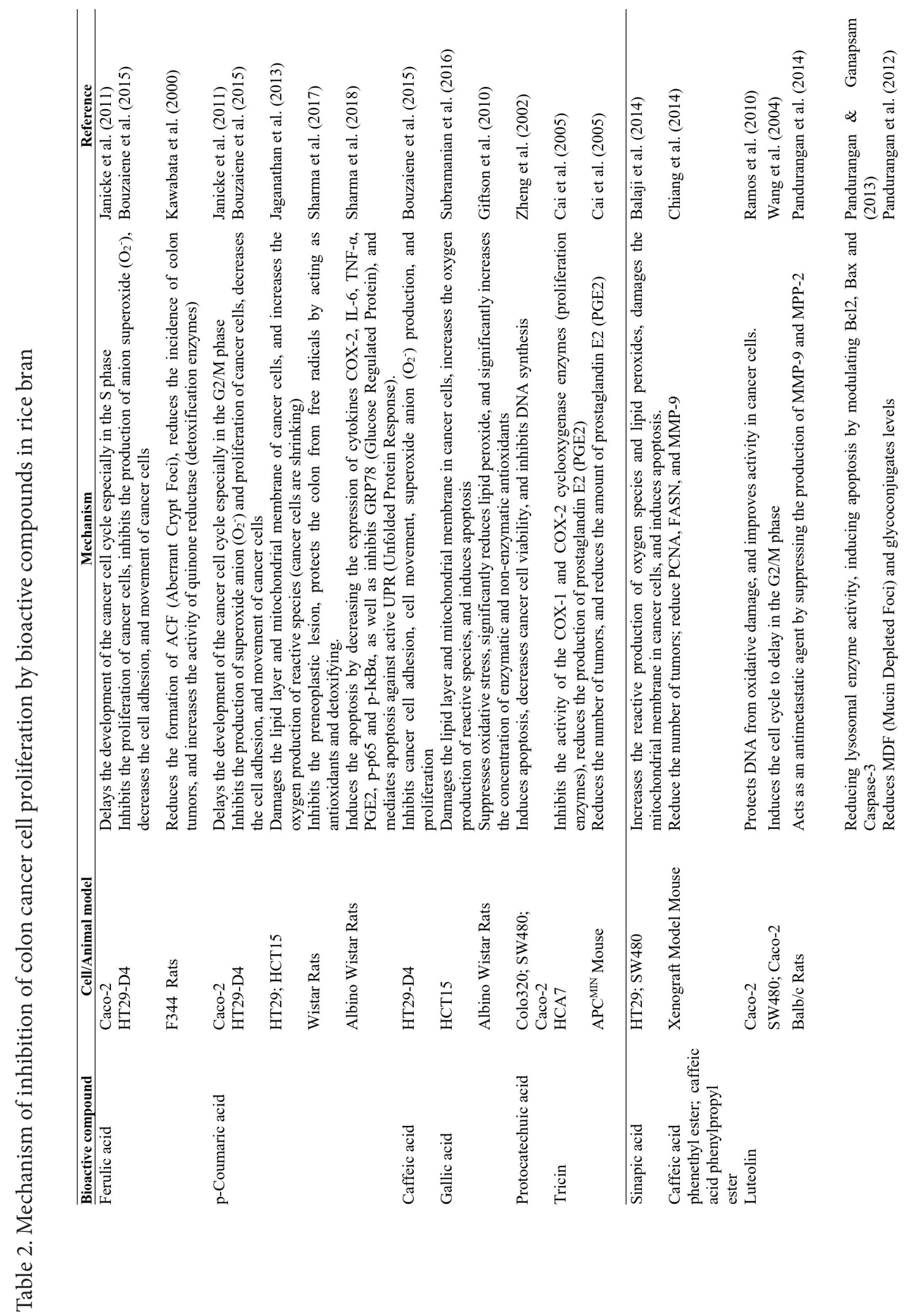




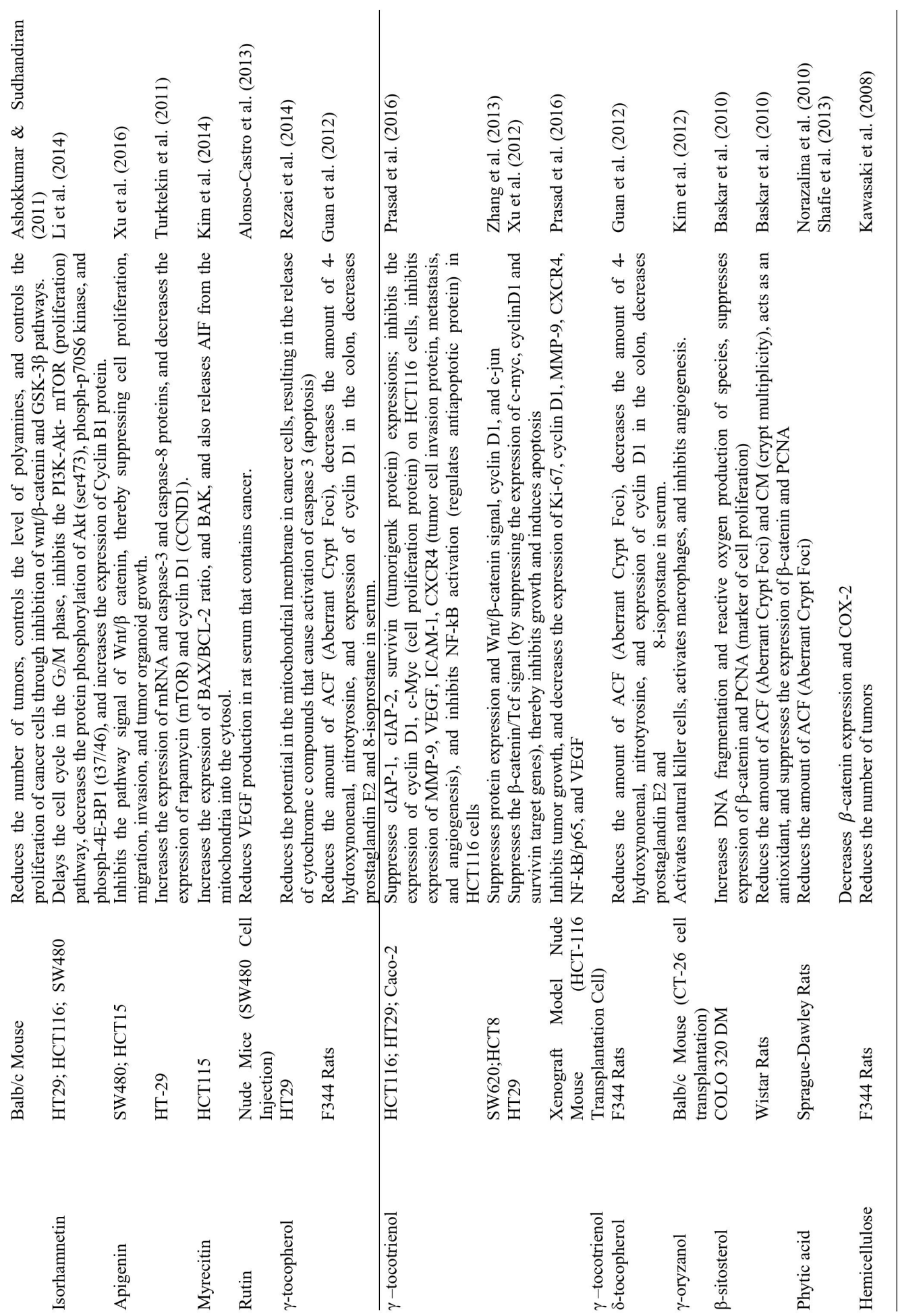


pathological parameter in colorectal cancer patients (Turktekin et al., 2011).

The study of the potential of rice bran as an antiproliferation of colon cancer cells through the mechanism of biocative compounds, can be seen more comprehensively from the results of in vitro and in vivo studies presented in Table 2. In vivo study studies are presented to strengthen the evidence that the bioactive component present in bran, also works effectively in inhibiting colon cancer cells in experimental animal.

The Development of Rice Bran as Functional Food

The development of functional food from rice bran in Indonesia is still very limited. Even though data collection of BPS-Statistics Indonesia, Rice production in 2018 was 56.54 million tons, which meant the availability of rice bran potential could reach 5.65 million tons (Central Bureau of Statistics, 2018), that matter make of the processing of rice bran into functional food, that will have a high economic value. Furthermore, the potential of health is also very promising because the content of bioactive compounds is varied, such as high phenolic acids content in nonpigmented rice (1.96 mg GAE/g ), red rice bran (4.39 mg GAE/g), and black rice bran 6.65 (mg GAE/g), data were shown here as $\%$ dry weight (Moongngram et al., 2012), and also contain other bioactive compound such as $\gamma$-oryzanol, tocopherol, tocotrienol, anthocyanins, and flavonoids.

Some countries in the world such as the United States, Australia, and Japan have developed rice bran processed products to the commercial stage, such as rice bran cereal, rice bran dessert or energy drinks, rice bran tortillas, rice bran flakes, and rice bran oil. This situation is very different in Indonesia, which are generally still found are traditional foods, such as rice bran bangket, rice bran jenang or rice bran porridge (Widowati, 2001). Lack of public awareness about the benefits of rice bran, rice bran quality that has not been standardized, and the lack of downstream industries interested in developing rice bran, become obstacles in the effort to develop rice bran as a functional food (Tuarita et al., 2017).

There were some processed rice bran products that had actually been developed at a laboratory scale, such as tempe enriched by rice bran, so resulting in a total phenolic increased by $67 \%$ with a ratio of rice bran and soybean ( 4 :6) a(Cempaka et al., 2018). Chips products with the main ingredient of wheat flour mixed with bran-enriched soybean had increased protein content by $73 \%$ with a ratio of soybean flour and wheat flour (3: 7) ${ }^{\mathrm{b}}$ (Cempaka et al., 2018).

Rice bran cereal (rice bran puffed cereal) with the application of twin screw extrusion technology, could produce a crisp texture and crisp resistance time in milk almost the same as or longer than commercial breakfast cereal products (Budijanto et al., 2012). Food bar from a mixture of rice bran flour and corn flour (10:90), was able to replace food bars made from wheat flour with insignificant differences in nutritional quality (protein, fat, carbohydrates), and qualify as emergency food with a total energy of $232.43 \mathrm{kcal} / 50 \mathrm{~g}$ of the ingredient (Kusumastuty et al., 2015). Furthermore, extrusion products from a mixture of rice and rice bran were reported to contain sufficient nutritional value and had the potential to be developed into snack products (Hermanianto et al., 2000).

The introduction of rice bran as a functional food is important to do. One way is by highlighting its health benefits as a marketing strategy. Thus, it is hoped to open the community paradigm and increase interest in the downstream industry as an effort to develop functional food from rice bran.

\section{Conclusion}

The bioactive compounds in rice bran consist of several categories, such as phenolic acids, flavonoids, anthocyanins, and steroidal compounds. The mechanisms of the bioactive compound rice bran in preventing colon cancer was classified by its function as an antioxidant, damage of the lipid layer and mitochondrial membrane, activation of immune cells, modulation of the cell cycle, inhibition of protein invasion of tumor cells, metastases, and angiogenesis, and activation of protein caspase to encourage apoptosis. The development of rice bran itself as a functional food product in Indonesia is still on a laboratory scale, although some are developed into traditional foods. Educating the public about the benefits 
of rice bran for health is a strategy for product development from rice bran raw material in the future.

\section{References}

Abdel-Aal, El-S.M., Young, J.C., \& Rabalski, I., 2006. Anthocyanin Composition in Black, Blue, Pink, Purple, and Red Cereal Grains. Journal of Agricultural and Food Chemistry,54(13):pp.4696-4704. doi. org/10.1021/jf0606609

Alauddina, M., Islama, J., Shirakawa, H., Kosekib, T., Ardiansyah, \& Komaia, M., 2017. Rice Bran as A Functional Food: an Overview of The Conversion of Rice Bran into A Superfood/ Functional Food : an Overview of The Conversion of Rice Bran into A Superfood/ Functional Food. London : InTechOpen.

Alonso-Castro, A.J., Domínguez, F., \& GarcíaCarrancá, A., 2013. Rutin Exerts Antitumor Effects on Nude Mice Bearing SW480 Tumor. Arch Med Res, 44(5):pp.346-351.doi: 10.1016/j.arcmed.2013.06.002

Anand, P., Sundaram, C., Jhurani, S., Kunnumakkara, A.B., \& Aggarwal, B.B., 2008. Curcumin and Cancer : An "Old-Age" Disease with an "Age Old" Solution. Cancer Lett, 267(1):pp.133164. doi: $10.1016 /$ j.canlet.2008.03.025

Anggraini, T., Novelina, Limber, U., \& Amelia, R., 2015. Antioxidant Activities of Some Red, Black and White Rice Cultivar from West Sumatra, Indonesia. Pak. J. Nutr, 14(2):pp.112117. doi: $10.3923 /$ pjn.2015.112.117

Ardiansyah, Shirakawa, H., Koseki, T., Ohinata, K., Hashizume, K., \& Komai, M., 2006. Rice Bran Fractions Improve Blood Pressure, Lipid Profile, and Glucose Metabolism in Stroke-Prone Spontaneously Hypertensive Rats. J Agric Food Chem, 54(5):pp.1914-1920. doi:10.1021/jf0525611

Ashokkumar, P., \& Sudhandiran, G., 2011. Luteolin Inhibits Cell Proliferation During Azoxymethane-Induced Experimental Colon Carcinogenesis Via Wnt $/ \beta$-Catenin Pathway. Invest New Drugs, 29(2):pp.273284.doi: 10.1007/s10637-009-9359-9

Badan Pusat Statistik, 2018. Luas Panen dan Produksi Beras di Indonesia 2018.

Balaji, C., Muthukumaran, J., Vinothkumar, R., \& Nalini, N., 2014. Anticancer Effects of Sinapic Acid on Human Colon Cancer Cell Lines HT-29 and SW480. International Journal of Pharmaceutical \& Biological Archives, 5(3):pp.176-183

Baskar, A.A., Ignacimuthu, S., Paulraj, G.M., \& AlNumair, K.S., 2010. Chemopreventive
Potential of beta-Sitosterol in Experimental Colon Cancer Model-an In Vitro and In Vivo Study. BMC Complementary and Alternative Medicine, 10(24):pp.1-10.doi: 10.1186/14726882-10-24

Bouzaiene, N.N., Jaziri, S.K., Kovacic, H., ChekirGhedira, L., Ghedira, K., \& Luis, J., 2015. The Effects of Caffeic, Coumaric and Ferulic Acid on Proliferation, Superoxide Production, Adhesion and Migration of Human Tumor In Vitro. Eur J Pharmacol, 766:pp.799-105. doi: 10.1016/j.ejphar.2015.09.044

Bray, F., Ferlay, J., Soerjomataram, I., Siegel, R.L., Torre, L.A., \& Jemal, A., 2018. Global Cancer Statistics 2018: GLOBOCAN Estimates of Incidence and Mortality Worldwide for 36 Cancers in 185 Countries. Ca Cancer J Clin, 68(6):pp.394-424. doi: 10.3322/caac.21492

Budijanto, S., Sitanggang, A.Z., Wiaranti, H., \& Koesbiantoro, B., 2012. Pengembangan Teknologi Sereal Sarapan Bekatul dengan Menggunakan Twin Screw Extruder. J. Pascapanen, 9(2):pp.63-69.doi.org/10.21082/ jpasca.v9n2.2012.63-69

Cai, H., Al-Fayez, M., Tunstall, R.G., Platton, S., Greaves, P., Steward, W.P., \& Gescher, A.J., 2005. The Rice Bran Constituent Tricin Potently Inhibits Cyclooxygenase Enzymes and Interferes with Intestinal Carcinogenesis in ApcMin Mice. Mol Cancer Ther, 4(9):pp.1287-1292.doi:10.1158/1535-7163. MCT-05-0165

${ }^{a}$ Cempaka, L., Eliza, N., Ardiansyah, D.D., Handoko, \& Astuti, R.M., 2018. Proximate composition, total phenolic content, and sensory analysis of rice bran tempe. Makara Journal of Science. 2018 Jun 6;22(2):pp.89-94. doi/org/10.7454/ mss.v22i2.9616

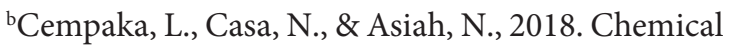
Composition and Sensory Analysis of Simulated Chips Based Rice Bran Tempe Flour. Current Research in Nutrition and Food Science. 6(3):pp.826-34. doi.org/10.12944/ CRNFSJ.6.3.25

Chiang, E.P., Tsai, S.Y., Kuo, Y.H., Pai, M.H., Chiu, H.L., Rodriguez, R.L., Tang, \& Feng-Yao., 2014. Caffeic Acid Derivatives Inhibit The Growth of Colon Cancer: Involvement of The PI3-K/Akt and AMPK Signaling Pathways. PLoS One, 9(6):e99631. doi.org/10.1371/ journal.pone.0099631

Focaccetti, C., Bruno, A., Magnani, E., Bartolini, D., Principi, E., Dallaglio, K., Bucci, E.O., Finzi, G., Sessa, F., Noonan, D.M., \& Albini, A., 2015. Effects of 5-Fluorouracil on Morphology, Cell Cycle, Proliferation, 
Apoptosis, Autophagy and ROS Production in Endothelial Cells and Cardiomyocytes. PLoS One, 10(2):pp.1-25.doi: 10.1371/ journal.pone.0115686

Garcia-Conesa, M.T., Wilson, P.D., Plumb, G.W., Ralph, J., \&Williamson, G., 1999. Antioxidant Properties of 4,4'-Dihydroxy-3,3'Dimethoxy- $\beta, \beta$ '-Bicinnamic Acid $(8,8$ Diferulic Acid, Non-cyclic Form). J. Sci. Food Agric, 79(3):pp.379-384.doi:10.1002/ (sici)1097-0010(19990301)79:3<379::aidjsfa259>3.0.co;2-v

Ghasemzadeh, A., Karbalaii, M.T., Jaafar, H.Z.E., \& Rahmat, A., 2018. Phytochemical Constituents, Antioxidant Activity, and Antiproliferative Properties of Black, Red, and Brown Rice Bran. Chem Cent J, 17;12(1):pp.17. doi: 10.1186/s13065-0180382-9

Ghoneum, M. \& Agrawal, S., 2011. Activation of Human Monocyte-Derived Dendritic Cells In Vitro By The Biological Response Modifier Arabinoxylan Rice Bran (MGN-3/Biobran). Int J Immunopathol Pharmacol, 24(4):pp.941948.doi:10.1177/039463201102400412

Giftson, J.S., Jayanthi, S., \& Nalini, N., 2010. Chemopreventive Efficacy of Gallic Acid, an Antioxidant and Anticarcinogenic Polyphenol, Against 1,2-Dimethyl Hydrazine Induced Rat Colon Carcinogenesis. Invest New Drugs, 28(3):pp.251-259. doi: 10.1007/ s10637-009-9241-9

Goufo, P., Pereira, J., Figuiredo, N., Oliveira, M.B.P.P., Carranca, C., Eduardo, A.S., \& Trindade, H., 2014. Effect of Elevated Carbon Dioxide $\left(\mathrm{CO}_{2}\right)$ on Phenolic Acids, Flavonoids, Tocopherols, Tocotrienols, $\quad \gamma$-Oryzanol and Antioxidant Capacities of Rice (Oryza sativa L.). J. Cereal Sci, 59(1):pp.15-24. doi. org/10.1016/j.jcs.2013.10.013

Guan, F., Li, G., Liu, A.B., Lee, M.J., Yang, Z., Chen, Y.K., Lin, Y., Shih, W., \& Yang, C.S., 2012. $\delta$ - and $\gamma$-Tocopherols, but not a-Tocopherol, Inhibit Colon Carcinogenesis in Azoxymethane-Treated F344 Rats. Cancer Prev Res (Phila), 5(4):pp.644-654.doi: 10.1158/1940-6207.CAPR-11-0521

Henderson, A.J., Ollila, C.A., Kumar, A., Borresen, E.C., Raina, K., Agarwal, R., \& Ryan, E.P., 2012. Chemopreventive Properties of Dietary Rice Bran: Current Status and Future Prospects. Adv Nutr, 3(5):pp.643-653. doi: 10.3945/an.112.002303

Hermanianto, J., Syarief, R., \& Wulandari, Z., 2000. Analisis Sifat Fisiokimia Produk Ekstrusi Hasil Samping Penggilingan Padi (Menir dan
Bekatul). Bul. Teknol. dan Industri Pangan, 11(1):pp.5-10.

Hosoda, K., Sasahara, H., Matsushita, K., Tamura, Y., Miyaji, M., \& Matsuyama, H., 2018. Anthocyanin and Proanthocyanidin Contents, Antioxidant Activity, and In Situ Degradability of Black and Red Rice Grains. Asian-Australas J Anim Sci, 31(8): pp.12131220.doi: 10.5713/ajas.17.0655

Huang, Y.P., \& Lai, H.M., 2016. Bioactive Compounds and Antioxidative Activity of Colored Rice Bran. Journal of Food and Drug Analysis, 24(3):pp.564-574. doi. org/10.1016/j.jfda.2016.01.004

Hui, C., Bin, Y., Xiaoping, Y., Long, Y., Chunye, C., Mantian M., \& Wenhua, L., 2010. Anticancer Activities of an AnthocyaninRich Extract From Black Rice Against Breast Cancer Cells In Vitro and In Vivo. Nutr Cancer, 62(8):pp.1128-1136. doi: $10.1080 / 01635581.2010 .494821$

[IARC] International Agency for Research on Cancer, 2018. Indonesia Source: Globocan 2018. The Global Cancer Observatory.

Islam, J., Koseki, T., Watanabe, K., Ardiansyah., Budijanto, S., Oikawa, A., Alauddin, M., Goto, T., Aso, H., Komai, M., \& Shirakawa, H., 2017. Dietary Supplementation of Fermented Rice Bran Effectively Alleviates Dextran Sodium Sulfate-Induced Colitis in Mice. Nutrients, 9(7):pp.747.doi:10.3390/ nu9070747

Jaganathan, S.K., Supriyanto, E., \& Mandal, M., 2013. Events Associated with Apoptotic Effect of p-Coumaric Acid in HCT-15 Colon Cancer Cells. World J Gastroenterol, 19(43):pp.77267734.doi: 10.3748/wjg.v19.i43.7726

Janicke, B., Hegardt, C., Krogh, M., Onning, G., Akesson, B., Cirenajwis, H.M., \& Oredsson, S.M., 2011. The Antiproliferative Effect of Dietary Fiber Phenolic Compounds Ferulic Acid and $p$-Coumaric Acid on The Cell Cycle of Caco-2 Cells. Nutr Cancer, 63(4):pp.611622. doi.org/10.1080/01635581.2011.538486

Katanasaka, Y., Ishii, T., Asai, T., Naitou, H., Maeda, N., Koizumi, F., Miyagawa, S., Ohashi, N., \& Oku N., 2010. Cancer Antineovascular Therapy with Liposome Drug Delivery Systems Targeted to BiP/GRP78. Int J Cancer, 127(11):pp.2685-2698. doi: 10.1002/ijc. 25276

Kawabata, K., Yamamoto, T., Hara, A., Shimizu, M., Yamada, Y., Matsunaga, K., Tanaka, T., \& Mori, H., 2000. Modifying Effects of Ferulic Acid on Azoxymethane-Induced Colon Carcinogenesis in F344 Rats. Cancer Lett, $\quad$ 157(1):pp.15-21.doi:10.1016/s0304- 
3835(00)00461-4

Kawasaki, B.T., Hurt, E.M., Mistree, T., \& Farrar, W.L., 2008. Targeting Cancer Stem Cells with Phytochemicals. Molecular Interventions, 8(4):pp.174-184.doi: 10.1124/mi.8.4.9

Kim, M.E., Ha, T.K., Yoon, J.H., \& Lee, J.S., 2014. Myricetin Induces Cell Death of Human Colon Cancer Cells Via BAX/ BCL2-Dependent Pathway.Anticancer Res, 34(2):pp.701-706

Kim, S.P., Kang, M.Y., Nam, S.H., \& Friedman, M., 2012. Dietary Rice Bran Component $\gamma$-oryzanol Inhibits Tumor Growth in Tumor-Bearing Mice. Mol. Nutr. Food Res, 56(6):pp.935-944

Kumar, S., 2014. The Importance of Antioxidant and Their Role in Pharmaceutical Science-A Review. Asian Journal of Research in Chemistry and Pharmaceutical Sciences, 1(1):pp.27-44

Kurniawati, M., Budijanto, S., \& Yuliana, N.D., 2016. Karakterisasi dan Indeks Glikemik Beras Analog Berbahan Dasar Tepung Jagung. J. Gizi Pangan, 11 (3):pp.169-174. doi. org/10.25182/jgp.2016.11.3.\%25p

Kusumastuty, I., Ningsih, L.F., \& Julia, A.R., 2015. Formulasi Food Bar Tepung Bekatul dan Tepung Jagung sebagai Pangan Darurat. Indonesia Journal of Human Nutrition, 2(2):pp.68-75. doi.org/10.21776/ ub.ijhn.2015.002.02.1

Lamberts, L., Bie, E.De., Derycke, V., Veraverbeke, W.S., Man, W.De, \& Delcour, J.A., 2016 Effect of Processing Conditions on Color Change of Brown and Milled Parboiled Rice. Cereal Chem, 83(1):pp.80-85. doi.org/10.1094/CC83-0080

Laokuldilok, T., Shoemaker, C.F., Jongkaewwattana, S., \& Tulyathan, V., 2011. Antioxidants and Antioxidant Activity of Several Pigmented Rice Brans. J. Agric. Food Chem, 59(1):pp.193199. doi: 10.1021/jf103649q

Law, B.M.H., Waye, M.M.Y., So, W.K.W., \& Chair, S.Y., 2017. Hypotheses on The Potential of Rice Bran Intake to Prevent Gastrointestinal Cancer Through The Modulation of Oxidative Stress. Int J Mol Sci, 18(7)pii: E1352.doi:10.3390/ijms18071352

Li, C., Yang, X., Chen, C., Cai, S., \& Hu, J., 2014. Isorhamnetin Suppresses Colon Cancer Cell Growth Through The PI3KAktmTOR Pathway. Mol Med Rep. 9(3):pp.935-940.doi: 10.3892/mmr.2014.1886

Limtrakul, D.P., Semmarath, W., \& Mapoung, S., 2019. Anthocyanins and Proanthocyanidins in Natural Pigmented Rice and Their Bioactivities
: Phytochemicals in Human Health. London : InTechOpen

Limtrakul, P., Yodkeeree, S., Pitchakarn, P., \& Punfa, W., 2016. Anti-Inflammatory Effects of Proanthocyanidin-Rich Red Rice Extract Via Suppression of MAPK, AP-1 and NF-kB Pathways in Raw 264.7 Macrophages. Nutr Res Pract, 10(3):pp.251-258.doi: 10.4162/ nrp.2016.10.3.251

Manickavasagan, A., Santhakumar, C., \& Venkatachalapathy, N., 2017. Brown rice. Switzerland : Springer Nature.

McIlwain, D.R., Berger, T., \& Mak, T.W., 2013. Caspase Functions in Cell Death and Disease. Cold Spring Harb Perspect Biol, 5(4):a008656. doi: 10.1101/cshperspect.a008656

Min, B., McClung, A., \& Chen, M.H., 2014. Effects of Hydrothermal Processes on Antioxidants in Brown, Purple and Red Bran Whole Grain Rice (Oryza sativa L.) Food Chem, 159:pp.106115. doi: 10.1016/j.foodchem.2014.02.164

Moongngram, A., Daomukda, N., \& Khumpika S., 2012. Chemical Compositions, Phytochemical, and Antioxidant Capacity of Rice Bran, Rice Bran Layer, and Rice Germ. APCBEC Procedia, 2:pp.73-79. doi. org/10.1016/j.apcbee.2012.06.014

Nakornriab, M., Sriseadka, T., \& Wongpornchai, S., 2008. Quantification of Carotenoid and Flavonoid Compounds in Brans of Some Thai Black Rice Cultivars Using Supercritical Fluid Extraction and High-Performance Liquid Chromatography-Mass Spectrometry. Journal of Food Lipids, 15(4):pp.488-503. doi. org/10.1111/j.1745-4522.2008.00135.x

Nasrallah, A. \& El-Sibai, M., 2014. Colorectal Cancer Causes and Treatments: A Minireview. The Open Colorectal Cancer Journal, 24(7):pp.14.doi: 10.2174/1876820201407010001

Norazalina, S., Norhaizan, M.E., Hairuszah, I., \& Norashareena, M.S., 2010. Anticarcinogenic Efficacy of Phytic Acid Extracted From Rice Bran on Azoxymethane-Induced Colon Carcinogenesis in Rats. Exp Toxicol Pathol. 62(3):pp.259-268.doi: 10.1016/j. etp.2009.04.002

Noviasari, S., Kusnandar, F., Setiyono, A., Budi, F.S., \& Budijanto, S., 2019. Profile of Phenolic Compounds, DPPH-Scavenging and Anti $\alpha$-amylase Activity of Black Rice Bran Fermented with Rhizopus oligosporus. Pertanika J. Trop. Agric. Sc, 42 (2):pp.489 501.

Oliveira, Mdos, S., Feddern, V., Kupsk, L., Cipolatti, E.P., Badiale-Furlong, E., de Souza-Soares, L.A., 2011. Changes in Lipid, Fatty Acids and 
Phospholipids Composition of Whole Rice Bran After Solid-State Fungal Fermentation. Bioresour Technol, 102(17):pp.8335-8338. doi: 10.1016/j.biortech.2011.06.025

Pandurangan, A.K., \& Ganapsam, S., 2013. Luteolin Induces Apoptosis in AzoxymethaneInduced Colon Carcinogenesis Through Involvement of Bcl-2, Bax, and Caspase-3. J Chem Pharm Res, 5(4):pp.143-148.

Pandurangan, A.K., Dharmalingam, P, Ananda, SK, Ganapasam S., 2012. Effect of Luteolin on The Levels of Glycoproteins During Azoxymethane-Induced Colon Carcinogenesis in Mice. Asian Pac J Cancer Prev, 13(4):pp.1569-1573.doi:10.7314/ apjcp.2012.13.4.1569

Pandurangan, A.K., Dharmalingam, P., Sadagopan, S.K., \& Ganapasam, S., 2014. Luteolin Inhibits Matrix Metalloproteinase 9 and 2 in Azoxymethane-Induced Colon Carcinogenesis. Hum Exp Toxicol, 33(11):pp.1176-1185.doi: 10.1177/0960327114522502

Pang, Y., Ahmed, S., Xu, Y., Beta, T., Zhu, Z., Shao, Y., \& Bao, J., 2017. Bound Phenolic Compounds and Antioxidant Properties of Whole Grain and Bran of White, Red and Black Rice. Food Chemistry, 240:pp.212-221.doi.org/10.1016/j. foodchem.2017.07.095

Pavlou, S., Wang, L., Xu, H., \& Chen, M., 2017. HigherPhagocytic Activity of ThioglycollateElicited Peritoneal Macrophages is Related to Metabolic Status of The Cells. J Inflamm (Lond), 14(4):pp.1-6. doi: 10.1186/s12950017-0151-x

Poulev, A., Chen, M.H., Cherravuru, S., Raskin, I., \& Belanger, F.C., 2017. Variation in Levels of The Flavone Tricin in Bran from Rice Genotypes Varying in Pericarp Color. Journal of Cereal Science, 79(7):pp.226232. doi.org/10.1016/j.jcs.2017.11.001

Prasad, M.N.N., Sanjay, K.R., Khatokar, M.S., Vismaya, M.N., \& Swamy, N., 2011. Health Benefits of Rice Bran - A Review. J Nutr Food Sci, 1(3) :pp.1-7. doi:10.4172/21559600.1000108

Prasad, S., Gupta, S.C., Tyagi, A.K., \& Aggarwal, B.B., 2016. $\gamma$-Tocotrienol Suppresses Growth Andsensitises Human Colorectal Tumours to Capecitabine in A Nude Mouse Xenograft Model by Down-Regulating Multiple Molecules. Br J Cancer. 115(7):pp.814-824. doi: $10.1038 /$ bjc. 2016.257

Pratiwi, R., \& Purwestri, Y.A., 2017. Black Rice as A Functional Food in Indonesia. Functional Foods in Health and Disease, 7(3):pp.182-
194. doi: 10.31989/ffhd.v7i3.310

Ramos, A.A., Pereira-Wilson, C., \& Collins, A.R., 2010. Protective Effects of Ursolic Acid and Luteolin Against Oxidative DNA Damage Include Enhancement of DNA Repair in Caco-2 Cells. Mutat Res, 692(1-2):pp. 6-11. doi: 10.1016/j.mrfmmm.2010.07.004

Rashid, N.Y.A., Razak, D.L.A., Jamaluddin, A., Sharifuddin, S.A., \& Long, K., 2015. Bioactive Compounds and Antioxidant Activity of Rice Bran Fermented with Lactic Acid Bacteria. Malaysian Journal of Microbiology, 11(2):pp.156-162. doi: $10.21161 / \mathrm{mjm} .12714$

Rezaei, M., Zeidooni, L., Hashemitabar, M., Razzazzadeh, S., Mahdavinia, M., \& Ghasemi, K., 2014. Gamma-Tocopherol Enhances Apoptotic Effects of Lovastatin in Human Colorectal Carcinoma Cell Line (HT29). Nutr Cancer, 66(8):pp.1386-1393. doi: 10.1080/01635581.2014.956250

Shafie, N.H., Mohd Esa, N., Ithnin, H., Md, Akim, A., Saad, N., \& Pandurangan, A.K., 2013. Preventive Inositol Hexaphosphate Extracted From Rice Bran Inhibits Colorectal Cancer Through Involvement of Wnt/-Catenin and COX-2 Pathways. Biomed Res Int, 2013:pp.1-10. doi: 10.1155/2013/681027

Shao, Y., Xu, F., Sun, X., Bao, J., \& Beta T., 2014. Identification and Quantification of Phenolic Acids and Anthocyanins as Antioxidants in Bran, Embryo and Endosperm of White, Red and Black Rice Kernels (Oryza sativa L.). Journal of Cereal Science, 59(2):pp.211218. doi.org/10.1016/j.jcs.2014.01.004

Sharma, S.H., Chellappan, D.R., Chinnaswamy, P., \& Nagarajan, S., 2017. Protective Effect of p-Coumaric Acid Against 1,2 Dimethylhydrazine Induced Colonic Preneoplastic Lesions in Experimental Rats. Biomed Pharmacother. 94:pp.577-588.doi: 10.1016/j.biopha.2017.07.146

Sharma, S.H., Rajamanickam, V., \& Nagarajan, S., 2018. Antiproliferative Effect of $p$-Coumaric Acid Targets UPR Activation By Downregulating Grp78 in Colon Cancer. Chem Biol Interact, 291:pp.16-28. doi: 10.1016/j.cbi.2018.06.001

Subramanian, A.P., Jaganathan, S.K., Mandal, M., Supriyanto, E., \& Muhamad, II., 2016. Gallic Acid Induced Apoptotic Events in HCT-15 Colon Cancer Cells. World J Gastroenterol, 22(15):pp.3952-3961. doi: 10.3748/wjg.v22. i15.3952

Sumczynski, D, Kotásková, E., bíková, H.D., \& Mlček J., 2016. Determination of Contents 
and Antioxidant Activity of Free and Bound Phenolics Compounds and In Vitro Digestibility of Commercial Black and Red Rice (Oryza sativa L.) Varieties. Food Chem, 211:pp.339-346.doi: 10.1016/j. foodchem.2016.05.081

Sun, Q., Spiegelman, D., Van, D.R.M., Holmes, M.D., Malik, V.S., Willett, W.C., \& Hu, F.B., 2010. White Rice, Brown Rice, and Risk of Type 2 Diabetes in US Men and Women. Arch Intern Med, 170(11):pp.961-969. doi: 10.1001/archinternmed.2010.109

Tuarita, M.Z., Sadek, N.F., Sukarno, Yuliana, N.D., \& Budijanto, S., 2017 Pengembangan Bekatul sebagai Pangan Fungsional: Peluang, Hambatan, dan Tantangan. Jurnal Pangan, 26(2):pp.167-176.

Turktekin, M., Konac, E., Onen, H.I., Alp, E., Yilmaz, A., \& Menevse, S., 2011. Evaluation of The Effects of The Flavonoid Apigenin on Apoptotic Pathway Gene Expression on The Colon Cancer Cell Line (HT29). J Med Food, 14(10):pp.1107-1117. doi: 10.1089/ jmf.2010.0208

Um, M.Y., Ahn, J., \& Ha, T.Y., 2013. Hypolipidaemic Effects of Cyanidin 3-Glucoside Rich Extract From Black Rice Through Regulating Hepatic Lipogenic Enzyme Activities. $J$ Sci Food Agric, 93(12):pp.3126-3128. doi: 10.1002/jsfa.6070

Wang, W., VanAlstyne, P.C., Irons, K.A., Chen, S., Stewart, J.W, \& Birt, D.F., 2004. Individual and Interactive Effects of Apigenin Analogs on G2/M Cell-Cycle Arrest in Human Colon Carcinoma Cell Lines. Nutrition and Cancer, 48(1):pp.106-114.doi: 10.1207/ s15327914nc4801_14

Widowati, S., 2001. Pemanfaatan Hasil Samping Penggilingan Padi dalam menunjang Sistem Agroindustri di Pedesaan. Buletin AgroBio, 4(1):pp.33-38.

Xia, X., Ling, W., Ma, J., Xia, M., Hou, M., Wang, Q., Zhu, H., \& Tang, Z., 2006. an AnthocyaninRich Extract from Black Rice Enhances Atherosclerotic Plaque Stabilization in
Apolipoprotein E-deficient Mice. The Journal of Nutrition, 136(8):pp.2220-2225.

Xu, M., Wang, S., Song, Y.U., Yao, J., Huang, K., \& Zhu, X., 2016. Apigenin Suppresses Colorectal Cancer Cell Proliferation, Migration and Invasion Via Inhibition of The Wnt/ $\boldsymbol{\beta}$-Catenin Signaling Pathway. Oncol Lett, 11(5):pp.3075-3080.doi: 10.3892/ ol.2016.4331

Xu, W., Du, M., Zhao, Y., Wang, Q., Sun, W., \& Chen, B., 2012. $\gamma$-Tocotrienol Inhibits Cell Viability Through Suppression of $\beta$-Catenin/Tcf Signaling in Human Colon Carcinoma HT29 Cells. J Nutr Biochem, 23(7):pp.800-807. doi:10.1016/j.jnutbio.2011.04.003

Yadav, R.K, Chae, Soo-Wan., Kim, Hyung-Ryong., \& Chae, H.J., 2014 Endoplasmic Reticulum Stress and Cancer. J Cancer Prev, 19(2):pp.7588. doi: 10.15430/JCP.2014.19.2.75

Younas, A., Bhatti, M.S., Ahmed, A., \& Randhawa, M.A., 2011. Effect of Rice Bran Supplementation on Cookie Baking. Pak. J. Agri. Sci, 48(2):pp.129-134.

Zhang, J.S., Li, D.M., Ma, Y., He, N., Gu, Q., Wang, F.S., Jiang, S.Q., Chen, B.Q., \& Liu, J.R. 2013. $\gamma$-Tocotrienol Induces Paraptosis-Like Cell Death in Human Colon Carcinoma SW620 Cells. PLoS One.E57779. doi.org/10.1371/ journal.pone.0057779

Zheng, Q., Hirose, Y., Yoshimi, N., Murakami, A., Koshimizu, K., Ohigashi, H., Sakata, K., Matsumoto, Y., Sayama, Y., \& Mori, H., 2002. Further Investigation of The Modifying Effect of Various Chemopreventive Agents on Apoptosis and Cell Proliferation in Human Colon Cancer Cells. J Cancer Res Clin Oncol, 128(10):pp.539-546. doi:10.1007/s00432002-0373-y

Zulfafamy, K.E., Ardiansyah, \& Budijanto, S., 2018. Antioxidative Properties and Cytotoxic Activity Against Colon Cancer Cell WiDr of Rhizopus oryzae and Rhizopus oligosporusFermented Black Rice Bran Extract. Curr. Res. Nutr Food Sci Jour, 6 (1) :pp.23-34. doi. org/10.12944/CRNFSJ.6.1.03 